\title{
Student Dispositions Toward STEM: Exploring an Engineering Summer Camp for Underrepresented Students (Work in Progress)
}

\section{Dr. Jeanna R. Wieselmann, Southern Methodist University}

Dr. Jeanna R. Wieselmann is a Research Assistant Professor at Southern Methodist University in Dallas, TX. Her research focuses on gender equity in STEM and maintaining elementary girls' interest in STEM through both in-school and out-of-school experiences. Dr. Wieselmann's research has explored student participation patterns in small group STEM activities. She is interested in STEM schools, integrated STEM curriculum development, and teacher professional development to support gender-equitable teaching practices.

\section{Prof. Richard Duschl, Southern Methodist University}

Executive Director, Caruth Institute for Engineering Education; Texas Instrument Distinguish Chair; PastPresident NARST (2008-11); Chair, NRC 2007 Report "Taking Science to School: Learning and Teaching Science in Grades K-8"; Research interests include designing integrated STEM learning environments the promote epistemic reasoning and argumentation discourse.

\section{Miss Kristine Reiley, SMU, Lyle School of Engineering, Caruth Institute for Engineering Education}

Kristine R. Reiley joined the SMU Lyle School of Engineering staff at Southern Methodist University (SMU) in March 2009 as an administrative contractor to assist with the operations of the Caruth Institute for Engineering Education (CIEE). In January 2010 she became an official SMU staff member of the Caruth Institute as a Program Specialist for the Executive Director. From January 2010 through December 2017 Kristine served as the Coordinator for the CIEE. Kristine is now the Program Specialist for K-12 Outreach and Summer Camps for the Caruth Institute for Engineering Education, the Assistant Director of TEDxSMU and the Executive Director of the Dallas Regional Science and Engineering Fair.

Prior to joining the CIEE, Kristine was a first grade teacher at First Baptist Academy (FBA) in Universal City, Texas for eight years. She was the first grade department chair from December 2002 to May 2009. While at FBA, Kristine was also appointed to the Extended Learning Services (ELS) department, which offered before school activities for the elementary students. She was the team leader for the summer activities program at FBA as well.

In addition to her faculty duties at FBA, Kristine administered entrance exams for new incoming elementary students. She developed and coordinated an elective reading program called Reading Plus for students who had difficulties in language arts. In her earlier days at FBA, Kristine served as the Head Coach for the FBA Boys Junior High Team from August 2001 to May 2004.

Kristine graduated from Sul Ross State University in Uvalde in 2000, with her B.A. in Education with an additional emphasis in English. In addition to being an avid sports fan, Kristine spends her free time with her dog and volunteering with her church, the Cary HOSTS program at Edward Cary Middle School, and the Presbyterian Children's Home and Services.

\section{Dr. Kenneth Berry, Southern Methodist University}

Dr. Kenneth Berry is the Associate STEM Director at the Caruth Institute in the Lyle School of Engineering at Southern Methodist University (SMU). He has worked as an education specialist at NASA's Jet Propulsion Laboratory until he received his doctorate in Educational Technology in 2001. He then taught at the Michael D. Eisner School of Education at California State University at Northridge (CSUN). In 2009, he moved to Texas to work at the Science and Engineering Education Center, and Caruth Institute of Engineering Education. He specializes in Engineering, STEM, and Project Based Learning instruction. 


\section{Student Dispositions Toward STEM: Exploring an Engineering Summer Camp for Underrepresented Students (Work in Progress)}

\section{Introduction}

Engineering fields continue to evolve and grow rapidly [1], resulting in an increasing demand for skilled workers [2]. However, representation within engineering fields is often inequitable, with women, Latinos, and African Americans underrepresented in science, technology, engineering, and mathematics (STEM) professions [3]. Research shows that students' career interests in middle and high school are predictive of whether they pursue and attain STEM degrees [4] - [6], so efforts to increase the representation of women and non-Asian minorities have often focused on providing students with early authentic opportunities in engineering. This pilot study investigates a university-based summer camp for students entering grades 9-12 and addresses the research question: How, if at all, are biological sex and grade related to student dispositions toward STEM following an engineering summer camp?

\section{Brief Literature Review}

Students' interest in engineering and other STEM fields often begins at a young age. For example, in a survey of nearly 8,000 individuals, Maltese and Cooper [7] found that STEM interest was most often initiated prior to grade 6 . Career interests as early as eighth grade are predictive of future career choice [6], [8], so it is important to foster young students' interest in engineering. Students' interest in STEM often decrease as they progress through their K-12 education, and these decreases are especially pronounced among girls [9], [10]. In addition to lower interest in STEM fields, girls also tend to have less positive competence beliefs than boys. For example, Eccles, Wigfield, Harold, and Blumenfeld [11] found differences in mathematics competency beliefs favoring boys as early as the first grade. These patterns often continue into high school, where despite equal mathematics ability, boys are more likely to view themselves as good at mathematics than girls [12]. Students' biological sex is the main factor related to engineering aspirations, and children as young as 10 years associate engineering with masculinity [13]. With a number of troubling patterns revealed in prior research, efforts are underway to support girls' interest, participation, and competency beliefs in STEM. Particularly given the relatively recent addition of engineering to K-12 instruction, it is important to consider whether out-of-school engineering experiences like summer camps can be supportive of these goals.

\section{Theoretical Framework}

This work draws upon the learning activation framework, which considers the dispositions, skills, and knowledge that characterize success in STEM learning experiences [14]. The original framework identified four dimensions of learning activation specifically related to science: fascination, values, competency beliefs, and scientific sensemaking. The framework and associated instruments have since been expanded to include STEM rather than just science. Within the STEM learning activation framework, the first three dimensions (fascination, values, 
and competency beliefs) remain the same. However, instead of scientific sensemaking, innovation stance is included as the fourth dimension.

First, fascination in STEM refers to an emotional and cognitive interest in STEM activities [15]. This positive affect and curiosity can provide intrinsic motivation for ongoing participation in STEM activities. Second, learners who value STEM believe it is important to know and do STEM because of both personal and societal needs [16]. Even if an individual does not find STEM fascinating, those who value STEM are more likely to engage in STEM learning [17], [18]. Third, competency beliefs in STEM refer to an individual's belief in his or her ability to succeed in STEM learning experiences [19]. Competency beliefs are related to ongoing engagement, effort, and persistence in STEM [20], so they serve as an important factor as students select courses and careers. Finally, innovation stance in STEM refers to an individual's comfort with taking risks, trying new things, welcoming new ideas, and sense of entrepreneurial spirit [21]. Such intellectual risk-taking is associated with creativity and higher interest [22] and is theorized to be linked to innovation in STEM [21].

Taken together, nurturing the learning activation dimensions can support student success in present STEM situations as well as increase their likelihood of participation and success in the future, forming positive feedback loops. According to Dorph et al. [14], this reinforcement occurs through four processes: (1) the choice to participate in additional optional learning experiences; (2) higher cognitive, behavioral, and affective engagement in learning experiences; (3) greater learning as a result of the increased participation and engagement; and (4) subsequent increases in the activation dimensions. The framework is based on the premise that dispositions, skills, and knowledge are malleable, so opportunities to engage in authentic engineering may influence students' future actions related to engineering.

\section{Methods}

\section{Context and participants.}

This pilot study was situated within the context of an engineering summer camp for high school students in the South-Central U.S. Students entering grades 9 and 10 attended a five-day camp with topics related to electrical, mechanical, civil, and environmental engineering, as well as computer science. The camp activities maintained a focus on hands-on learning opportunities and small group projects. For example, the students created a robot that had to complete an obstacle course in competition against an opponent. They built and coded their robot, and they also built a bridge that was incorporated into the competition obstacle course.

Students entering grades 11 and 12 attended a two-week residential summer camp, during which they were presented with a real-world challenge and tasked with designing a prototype to meet the challenge criteria and constraints. Their challenge was to create a product that would make the "Makerspace of Tomorrow" more accessible to people with disabilities through the use of mechanical, electrical, civil, and computer engineering. Students in this camp had access to a 1,200 square foot design space with 3D printers, a laser cutter, vinyl cutter, power tools, and miscellaneous supplies. 
Undergraduate engineering students served as camp counselors, and camp sections for girls and boys were run separately, maintaining a single-sex learning environment. Although it is important to note that gender is more complicated than a simple binary, that was the approach utilized within the summer camp context. All students were from disadvantaged schools and received full scholarships to attend the camp. A total of 50 participants were included in this study.

\section{Data collection and analysis.}

This study used four Activation Lab survey instruments [15], [16], [19], [21] to measure camp participants' fascination in STEM, competency beliefs in STEM, valuing of STEM, and innovation stance in STEM. Each item includes response options on a four-point Likert scale. The STEM fascination scale has eight items (e.g., I like to figure out how things work; I wish I could build things more often). The STEM values scale is composed of 13 items (e.g., Engineers make the world a better place to live; Knowing science is important for being a good citizen). The STEM competency beliefs scale has 12 items (e.g., I can understand scientific information on websites for kids my age; I think I am very good at solving problems). Finally, the STEM innovation stance scale has 12 items (e.g., I share my design ideas even if I am not sure they will work; I often come up with ideas no one else has).

The surveys were administered at the end of the camp, allowing for an exploration of differences in student dispositions based on grade and sex. Table 1 shows mean scores on each survey scale for girls and boys in the two grade bands.

Table 1. Means by Grade and Sex

\begin{tabular}{llccc}
\hline & \multicolumn{2}{c}{ Grades 9-10 } & \multicolumn{2}{c}{ Grades 11-12 } \\
\cline { 2 - 5 } \multicolumn{1}{c}{ Scale } & $\begin{array}{c}\text { Girls } \\
(\mathrm{n}=12)\end{array}$ & $\begin{array}{c}\text { Boys } \\
(\mathrm{n}=15)\end{array}$ & $\begin{array}{c}\text { Girls } \\
(\mathrm{n}=13)\end{array}$ & $\begin{array}{c}\text { Boys } \\
(\mathrm{n}=10)\end{array}$ \\
\hline STEM Fascination (32 possible points) & 23.17 & 25.53 & 24.38 & 27.6 \\
STEM Values (52 possible points) & 36.00 & 40.07 & 38.54 & 41.70 \\
STEM Competency Beliefs (48 possible points) & 31.58 & 38.20 & 34.54 & 39.30 \\
STEM Innovation Stance (48 possible points) & 35.25 & 39.07 & 37.69 & 39.50 \\
\hline
\end{tabular}

A two-way ANOVA was used with grade (9-10 vs. 11-12) and sex as predictor variables, and the survey scores as dependent variables. Listwise deletion was used for missing data, and the resulting 50 participants are included in this study.

\section{Findings}

The two-way ANOVA analysis revealed a statistically significant main effect for sex on the STEM fascination scale, as shown in Table $2[\mathrm{~F}(1,46)=7.15 ; \mathrm{p}<.05]$. 
Table 2. STEM Fascination

\begin{tabular}{lllll}
\hline Predictor & $\begin{array}{l}\text { Type III Sum } \\
\text { of Squares }\end{array}$ & $d f$ & $\mathrm{~F}$ & $\mathrm{p}$ \\
\hline Intercept & 31008.492 & 1 & 7.154 & .000 \\
Sex & 95.311 & 1 & 2.477 & $.010^{*}$ \\
Grade & 33.001 & 1 & .165 & .122 \\
Sex*Grade & 2.203 & 1 & 2.48 & .686 \\
Error & 612.877 & 46 & & \\
\hline
\end{tabular}

$* p<.05$

The main effect for sex was also statistically significant on the STEM values scale $[\mathrm{F}(1,46)=$ $6.76, \mathrm{p}<.05]$, as shown in Table 3 .

Table 3. STEM Values

\begin{tabular}{lllll}
\hline Predictor & $\begin{array}{l}\text { Type III Sum } \\
\text { of Squares }\end{array}$ & $d f$ & $\mathrm{~F}$ & $\mathrm{p}$ \\
\hline Intercept & 74731.014 & 1 & 3158.817 & .000 \\
Sex & 159.814 & 1 & 6.755 & $.013^{*}$ \\
Grade & 53.235 & 1 & 2.250 & .140 \\
Sex*Grade & 2.506 & 1 & .106 & .746 \\
Error & 1088.264 & 46 & & \\
\hline
\end{tabular}

$* \mathrm{p}<.05$

The final statistically significant effect was the main effect for sex on the STEM competency beliefs scale $[\mathrm{F}(1,46)=18.096, \mathrm{p}<.01]$, as demonstrated in Table 4 .

Table 4. STEM Competency Beliefs

\begin{tabular}{lllll}
\hline Predictor & $\begin{array}{l}\text { Type III Sum } \\
\text { of Squares }\end{array}$ & $d f$ & $\mathrm{~F}$ & $\mathrm{p}$ \\
\hline Intercept & 63095.026 & 1 & 2883.205 & .000 \\
Sex & 396.006 & 1 & 18.096 & $.000^{* *}$ \\
Grade & 50.299 & 1 & 2.298 & .136 \\
Sex*Grade & 10.527 & 1 & .481 & .491 \\
Error & 1006.647 & 46 & & \\
\hline
\end{tabular}

$* * p<.01$

There were no statistically significant effects for sex on the STEM innovation stance scale (see Table 5). In addition, the main effect for grade was not statistically significant for any of the dependent variables, and there were no statistically significant interaction effects of sex and grade. 
Table 5. STEM Innovation Stance

\begin{tabular}{lllll}
\hline Predictor & $\begin{array}{l}\text { Type III Sum } \\
\text { of Squares }\end{array}$ & $d f$ & $\mathrm{~F}$ & $\mathrm{p}$ \\
\hline Intercept & 70215.200 & 1 & 2072.504 & .000 \\
Sex & 96.761 & 1 & 2.856 & .098 \\
Grade & 25.294 & 1 & .747 & .392 \\
Sex*Grade & 12.345 & 1 & .364 & .549 \\
Error & 1558.453 & 46 & & \\
\hline
\end{tabular}

\section{Discussion and Next Steps}

This study revealed sex differences in students' STEM fascination, valuing of STEM, and competency beliefs in STEM. Among the 50 participants in this study, boys reported greater fascination, competency beliefs, and valuing of STEM. This finding, while not surprising given prior research findings [9] - [12], is cause for ongoing concern. Notably, there was no statistically significant difference between girls and boys in relation to their STEM innovation stance. This finding warrants additional research to explore how to leverage girls' innovation and creativity to increase their interest in engineering. For example, explicit reference to creativity in engineering or activities with clear opportunities to be creative may be of particular interest to girls.

There were no statistically significant main effects for grade in relation to students' fascination, valuing, competency beliefs, and innovation stance in STEM. While prior studies have shown that STEM interest tends to decrease with time [9], [10], that was not the case in this study. Although this is a promising finding, it may be due to self-selection effects of students choosing to attend the engineering camp and requires further investigation.

As this research develops beyond the pilot stage, several important considerations must be made. First, because the pilot used the surveys at one point in time, it is not possible to determine whether camp activities had a positive effect on students' dispositions. Future studies should use a pre-post design to explore whether camp experiences are related to any shifts in students STEM fascination, valuing of STEM, competency beliefs, or innovation stance. Second, although students in this study came from disadvantaged schools, there were likely self-selection effects in choosing to attend the camp. Thus, these students cannot be considered representative of the population of high-schoolers in general. A comparison group of peers who do not attend the engineering summer camp would help disentangle the self-selection effects. Finally, longitudinal work of those youth who attend more than one year of camps is needed to more fully understand the experiences of underrepresented students as they consider whether to pursue programs of study and careers in engineering. 


\section{References}

[1] U.S. Department of Commerce, The competitiveness and innovative capacity of the United States. Washington, DC: U.S. Department of Commerce, 2012.

[2] President's Council of Advisors on Science and Technology, Report to the President: Prepare and Inspire: K-12 Education in Science, Technology, Engineering, and Mathematics (STEM) for America's Future. Washington, DC: Executive Office of the President, 2010.

[3] National Science Foundation, Women, Minorities, and Persons with Disabilities in Science and Engineering: 2019. Arlington, VA: National Center for Science and Engineering Statistics, March 2019.

[4] A. V. Maltese, C. S. Melki, and H. L. Wiebke, "The nature of experiences responsible for the generation and maintenance of interest in STEM," Science Education, vol. 98, pp. 937962, 2014.

[5] A. V. Maltese and R. H. Tai, "Pipeline persistence: Examining the association of educational experiences with earned degrees in STEM among U.S. students," Science Education, vol. 95, pp. 877-907, 2011.

[6] R. T. Tai, C. Q. Liu, A. V. Maltese, and X. Fan, "Planning early for careers in science," Science, vol. 312, pp. 1143-1144, 2006.

[7] A. V. Maltese and C. S. Cooper, "STEM pathways: Do men and women differ in why they enter and exit?" AERA Open, vol. 3, pp. 1-16, 2017.

[8] B. Lindahl, “A longitudinal study of students' attitudes towards science and choice of career," Paper presented at the $80^{\text {th }}$ NARST International Conference, New Orleans, LA. NARST, 2007.

[9] L. Archer, et al., “'Doing' science versus 'being' a scientist: Examining 10/11-year-old schoolchildren's constructions of science through the lens of identity," Science Education, vol. 94, pp. 617-639, 2010.

[10] P. M. Sadler, G. Sonnert, Z. Hazari, and R. Tai, "Stability and volatility of STEM career interest in high school: A gender study," Science Education, vol. 96, pp. 411-427, 2012.

[11] J. Eccles, A. Wigfield, R. D. Harold, and P. Blumenfeld, "Age and gender differences in children's self- and task perceptions during elementary school," Child Development, vol. 64, pp. 830-847, 1993.

[12] S. J. Correll, "Gender and the career choice process: The role of biased self-assessments," American Journal of Sociology, vol. 106, pp. 1691-1730, May 2001. 
[13] J. Moote, L. Archer, J. DeWitt, and E. MacLeod, "Comparing students' engineering and science aspirations from age 10 to 16: Investigating the role of gender, ethnicity, cultural capital, and attitudinal factors," Journal of Engineering Education, vol. 109, pp. 34-51, Jan. 2020.

[14] R. Dorph, M. A. Cannady, and C. Schunn, "How science learning activation enables success for youth in science learning," Electronic Journal of Science Education, vol. 20, pp. 49$85,2016$.

[15] Y.-F. Chen, M. A. Cannady, C. Schunn, and R. Dorph, "Measures technical brief: Fascination in STEM," Activation Lab. [Online]. Available: http://activationlab.org/tools/.

[16] Y.-F. Chen, M. A. Cannady, C. Schunn, and R. Dorph, "Measures technical brief: Values in STEM," Activation Lab. [Online]. Available: http://activationlab.org/tools/.

[17] M. M. Chiu and Z. Xihua, "Family and motivation effects on mathematics achievement: Analyses of students in 41 countries," Learning and Instruction, vol. 18, pp. 321-336, 2008.

[18] J. S. Eccles, "Subjective task value and the Eccles et al. model of achievement-related choices," in Handbook of Competence and Motivation, A. J. Elliot and C. S. Dweck, Eds. New York, NY: The Guilford Press, 2005, pp. 105-121.

[19] Y.-F. Chen, M. A. Cannady, C. Schunn, and R. Dorph, "Measures technical brief: Competency beliefs in STEM," Activation Lab. [Online]. Available: http://activationlab.org/tools/.

[20] D. H. Schunk, J. R. Meece, and P. R. Pintrich, Motivation in Education: Theory, Research and Applications ( $4^{\text {th }}$ ed.). New York, NY: Pearson, 2014.

[21] Y.-F. Chen, M. A. Cannady, C. Schunn, and R. Dorph, "Measures technical brief: Innovation stance in STEM," Activation Lab. [Online]. Available: http://activationlab.org/tools/.

[22] R. A. Beghetto, "Correlates of intellectual risk taking in elementary school science," Journal of Research in Science Teaching, vol, 46, pp. 210-223, 2009. 